\title{
7 TH MID EUROPEAN CLAY CONFERENCE, DRESDEN, GERMANY, SEPTEMBER 2014: OVERVIEW OF THE CLAY MINERALOGICAL STUDIES
}

This Open Access (OA) special issue of Clay Minerals includes papers presented at the $7^{\text {th }}$ Mid-European Clay Conference held on 16-19 September, 2014 in DresdenRadebeul, Germany. Clay groups from eastern- and midEuropean countries established in 2001 the first joint meeting called the "Mid-European Clay Conference" (MECC), to be held every second year. In 2014 the German-Austrian-Swiss Clay Group (DTTG) was in charge of the organization and is proud to fund the present OA issue. A broad spectrum of themes presented at this conference covered the importance of clay minerals and clays in geotechnical engineering, in the production of hydrocarbons, the storage of $\mathrm{CO}_{2}$, the disposal of radioactive waste and other industrial applications, as well as classical subjects such as soil mineralogy, crystallography, diagenesis, surface properties of clay minerals and new developments in analytical methods.

Almost 30 manuscripts were submitted for possible publication in this special issue, of which the maximum possible number of 12 manuscripts was accepted finally. The topics covered in these manuscripts reflect the variability of themes presented at the conference. Additional manuscripts will be published in future, regular issues of Clay Minerals.

Wilkinson (2015) treats the question of whether nucleation of clay minerals controls the rate of diagenesis in sandstones. Because of the small size of clay minerals a large number of crystals must be nucleated to form an authigenic cement in sandstone. The rate of nucleation of a mineral is very different from the rate of crystal growth. However, this has, until now, not been considered adequately as a rate-determining process, which may account partially for the discrepancy between numerical computer simulations of both natural diagenesis and of reactions induced by the injection of $\mathrm{CO}_{2}$ for storage or enhanced oil recovery. This work was presented as the 'Clay Minerals Group Lecture' of the British Clay Minerals Group (CMG) at MECC.

*E-mail: christid@tuc.mred.gr

DOI: $10.1180 /$ claymin.2015.050.3.00
Warr and Ferreiro Mählmann (2015) summarized the round-table discussion at the MECC about new recommendations for illite Kübler index standardization procedures, including new adjustments of the upper and lower boundary limits of the Crystallinity Index Standard (CIS) scale based on an interlaboratory correlation.

Ufer and Kleeberg (2015) show the application of parametric Rietveld refinement to characterize stacking defects that occur frequently in clay minerals. In their approach, a set of different measurements of the same sample was collected and fitted in one combined refinement process by connection of the structural models via external parameters, such as different sample pre-treatments and the use of random powder and oriented samples.

Dietel et al. (2015) characterized the crystal chemistry and structural parameters of a Na-rich rectorite from Arkansas, USA, as an interstratification of Na-dominated brammallitic (non-swelling) and beidellitic (swelling) layers by combining various methods such as X-ray diffraction and fluorescence, simultaneous thermal analysis coupled with mass spectrometry and TEM investigation.

The paper by Táborosi and Szilagyi (2015) is dedicated to the development of molecular cluster models for exfoliated kaolinite. These molecular models include both the octahedral and tetrahedral sheets of kaolinite and offer a structural platform for adsorption, intercalation, and delamination studies of exfoliated kaolinite at the nano-scale level. This is of great importance, since the knowledge of structure and particularly the differences between the exfoliated and original kaolinite hold the key for rationalized design of clay-based nanocomposite materials with tailored functionality.

Zsirka et al. (2015) describe two different preparation methods of kaolinite-based nanostructures. With mechanochemical treatment, pseudo-hexagonal and short tubular-type nanostructures were created; with a three-step intercalation process mainly tubular, or halloysite-like nanostructures were obtained. 
Tokarský et al. (2015) studied the effect of montmorillonite particles on the alignment of conducting polyaniline chains in differently prepared composites. With a combination of various experimental and modelling methods the successful intercalation was confirmed and characterized. The nanocomposites showed a greater and more anisotropic electrical conductivity than the polyaniline, prepared similarly, with a selective transmittance in the range $450-650 \mathrm{~nm}$.

Schampera et al. (2015) characterized the external interface of an organoclay prepared from hexadecylpyridinium and bentonite with a combination of X-ray photoelectron spectroscopy and classical molecular dynamics simulations. The combination of experimental and modelling methods provided complementary and consistent insight into the orientation of the organic cations on the external surfaces of the montmorillonite.

Kulenkampff et al. (2015) applied positron-emissiontomography for direct observation of positron-emitting radiotracers to reveal anisotropic and heterogeneous effects in diffusion in Opalinus clay samples. The observed spatial variance of diffusion on the $\mathrm{cm}$-scale has implications for understanding the fundamental process and for diffusional transport modelling.

Two papers are dedicated to geotechnical applications of clays. Haase and Schanz (2015) studied Cabentonite-polyacrylamide composites prepared with differently charged polymers and various polymer-Cabentonite ratios. The composites were characterized in terms of their macroscopic hydro-mechanical behaviour coupled with their microscopic structural and composite-formation characteristics.

Wolters et al. (2015) describe a multilayer sealing system (SANDWICH) installed at the Ibbenbüren coalmine (Germany) with self-compacting, highdensity bimodal bentonite blends as sealing material. The results of the swelling pressure testing program showed that all requirements for the emplacement of the building materials were fulfilled allowing a successful underground construction of the sealing system.

Finally, Garcia-Valles et al. (2015) investigated the mineralogy and thermal properties of kaolin from Mexican deposits from Acoculco (Puebla), Agua Blanca (Hidalgo) and Huayacocotla (Veracruz) at the eastern Trans-Mexican Volcanic Belt, for their suitability as raw material for the ceramic industry.

\section{REFERENCES}

Dietel J., Steudel A., Warr L.N. \& Emmerich K. (2015) Crystal chemistry of Na-rich rectorite from
North Little Rock, Arkansas. Clay Minerals, 50, 297-306.

Garcia-Valles M., Pi T., Alfonso P., Canet C., Martínez S., Jiménez-Franco A., Tarrago M. \& Hernández-Cruz B. (2015) Kaolin from Acoculco (Puebla, Mexico) as raw material: Mineralogical and thermal characterization. Clay Minerals, 50, 405-416.

Haase H. \& Schanz T. (2015) Hydro-mechanical properties of Calcigelpolyacrylamide composites. Clay Minerals, 50, 377-389.

Kulenkampff J., Gründig M., Zakhnini A., Gerasch R. \& Lippmann-Pipke J. (2015) Process tomography of diffusion, using PET, to evaluate anisotropy and heterogeneity. Clay Minerals, 50, 369-375.

Schampera B., Solc R., Woche S. K., Mikutta R., Dultz S., Guggenberger G. \& Tunega D. (2015) Surface structure of organoclays as examined by X-ray photoelectron spectroscopy and molecular dynamics simulations. Clay Minerals, 50, 353-367.

Táborosi A. \& Szilagyi R.K. (2015) Realistic molecular cluster models for exfoliated kaolinite. Clay Minerals, 50, 307-327.

Tokarský J., Peikertová P., Kulhánková L., Kutláková K. L., Neuwirthová L., Matějka V., Stŷskala V. \& Čapová P. (2015) Functional nanostructures of montmorillonite with conducting polyaniline. Clay Minerals, 50, 341-351.

Ufer K. \& Kleeberg R. (2015) Parametric Rietveld refinement of coexisting disordered clay minerals. Clay Minerals, 50, 287-296.

Warr L.N. \& Ferreiro Mählmann R. (2015) Recommendations for Kübler Index standardization. Clay Minerals, 50, 283-286.

Wilkinson M. (2015) Does the nucleation of clay minerals control the rate of diagenesis in sandstones? Clay Minerals, 50, 275-281.

Wolters F., Baille W., Emmerich K., Schmidt E., Wolters C., Königer F., Kunz J., Krase V. \& Schellhorn M. (2015) High-density bimodal bentonite blends for hydraulic sealings at the Ibbenbüren coalmine. Clay Minerals, 50, 391-403.

Zsirka B., Horváth E., Makó É., Kurdi R. \& Kristóf J. (2015) Preparation and characterization of kaolinite nanostructures: reaction pathways, morphology and structural order. Clay Minerals, 50, 329-340.

G.E. Christidis*

Professor of Economic Geology-Industrial

Mineralogy, Technical University of Crete, School of Mineral Resources Engineering, 73100 Chania,

Greece

Michael Plötze and Katja Emmerich, Guest Editors

Helge Stanjek, Associate Editor

August 2015 